\title{
The Efficiency of Using the Interactive Smartboard in Social Studies to Increase Students' Achievement and Tendency Toward the Subject Matter in the State of Qatar
}

\author{
Manal Hendawi \\ Qatar University \\ Qatar \\ Mohammad Rajab Nosair \\ Qatar University \\ Qatar
}

\begin{abstract}
This research aims to determine the effectiveness of the use of interactive smartboard techniques and applications in teaching a unit of a social studies curriculum for preparatory stage students in Qatar. The selected sample (47 students) is distributed into two groups, the experimental group which studied a chosen unit using the interactive smartboard, and the other group, the control group, which studied the same lesson plan conventionally. The two methods administered to the groups, before and after the experiment, are codified through a cognitive performance evaluation using the three stages of Bloom, and a structured assessment of the inclination towards social studies is applied. All groups are taught the same unit, prepared by the same teacher, but with a different method of teaching. To statistically test the research hypotheses, a quantitative comparison between the scores of the two groups before and after the experiment is carried out. The results indicate that the differences between the two groups in average values in favor of the trial group are statistically significant.
\end{abstract}

Keywords: Smartboard; Achievement; Tendency; Efficiency; Social Studies

\section{Introduction}

Social studies is an essential field in education, contributing significantly to human character, the various possibilities of problem-solving and logical thinking, the development of the human social senses, and the creation of social identity, including the nature of knowledge and attitudes that help students understand. 
The Qatar Ministry of Education and Higher Education (MoE) affirms that the State of Qatar puts science, technology and innovation at the top of its national priorities and integrates them into its National Vision 2030 strategic plans and objectives. Research studies support the view that today's use of teaching technology in classrooms is crucial for education as mentioned in the study of Kurt \& Dindar (2012). The MoE agrees that integrating technology into the culture increases the effectiveness of learning and student accomplishment and emphasizes technology incorporation in social studies. The MoE provides curriculum instructions to coordinators and teachers in the field.

Government schools in Qatar are provided with interactive whiteboards or interactive display devices, or both, to enrich the educational process and keep pace with progress. Using their programs and tools, teachers can prepare and present, in interesting ways, various lessons.

Using the software, various parts of the screen can be shown, engineering devices can be used, a network of crossed lines can be shown, shapes, colours and various types of font can be used, and documentation and explanations of the events on screen can be given by the system (MoE, 2019).

The interactive smartboard has an impact on the functioning of the educational process. It facilitates learning. Therefore, many studies have been conducted on the use of smartboards in teaching. However, the researchers have conducted a search of the literature and do not find any direct or indirect research related to the use of smartboards in teaching social studies in Qatar. Therefore, this study is considered the first to address using smartboard technology in the teaching of social studies in the State of Qatar.

The study focuses on the impact of using the smartboard on the level of achievement of middle school students. The value of this analysis stems from:

1. Keeping up with the times technologically and meeting new educational needs, in line with the policy of the Qatari Ministry of Education and Higher Education to integrate technology in education.

2. This research may motivate other researchers to conduct similar studies in other specialties, considering achievement or other variables.

3. The Qatar MoE may take the results of this study, and formally generalize the use of smartboards in all social studies classes in government schools.

\section{Literature Review}

\subsection{Importance of using a smartboard}

With the rapid progress of information systems and communication resources, direct contact and connection between the components of the teaching and learning (the teacher, student and textbook) is no longer the primary resources for receiving knowledge. 
Information and communication technology play an essential role in all aspects of life, as it transforms civilization and helps the reunion among nations, as distances become reduced and no barriers exist between members of the community. The whole world becomes like a village. The challenges that the world faces today and the change occurring in many aspects of life, make it necessary for educational institutions to adopt modern educational technologies. Scientific development has brought with it many instructional techniques that can be used to create areas of expertise for learners. Students having a high degree of competence qualifies them to meet challenges (Al Hassan \& $\mathrm{Al}$ Badawi, 2016).

The use of technology such as computers, smartboards, projectors, the internet, and many other things, in education is theorized to be one of the best ways to bring effectiveness to teaching. Over the years, there have been many studies like Almajali (2016), Oigara(2017), Dahlan (2014) examined whether these technologies are useful in teaching, and interactive smartboards are among the areas of study. We can safely say that the interactive smartboard has taken over from the overhead projector in school classrooms throughout the education world.

Smartboards have many ways to enhance the student learning experience. The use of smartboard technology provides students and learners with support, knowledge and skills using optical features. It can make lessons fun, because the teacher can use many different styles and teaching aids. Furthermore, it helps all kinds of students, each with individual requirements, to understand the lesson at the same time. For example, 'visual' students can see the smartboard, while students that learn 'by hand' can touch the smartboard.

Using a smartboard in teaching helps increase the motivation of the learners. A study in 2010-2011 in which a school provided an interactive whiteboard in classrooms, shows that, after some time, a drastic change was affected in the school system. Some classes became smart classrooms, and the study found that the smartboard had a massive impact on the students' knowledge and achievement (Davidovitch \& Yavich, 2017).

Many types of research show that learners learn better when they are fully involved in the lesson activities. With the smartboard being available in the classroom, every student has the opportunity to use the smartboard, and this allows them to actively become part of the learning process. For example, most smartboards have the option of using the fingers to write directly on them. This kind of interactivity gives learners the opportunity to write or even draw. As Socrates said, "reading is very different from memorizing a speech or learning by doing" (Rotry, 2005). In a study carried out in 2014Ainur and Arasaln say that smartboards can be used to increase the involvement of students in the study process in the classroom.

According to Cox (2019), Research shows that students benefit best if they participate entirely, and true education is one of the best ways to achieve this. 
For instance, when teaching social science, learning and understanding what a world map looks like will be different if the teacher describes the map to the students rather than encouraging them to participate in drawing the map on the smartboard. Thus, the teacher increases the level of establishment of the information in the student's mind (Collins, 2009). Another advantage is that students can learn how to work together collaboratively.

By using smartboards in classrooms, students have the ability to access the internet, where they can view websites or videos. Thus, students can easily access different tools to complete project or perform research and keep up to date with developments around the world (Bates, 2003). It is vital to use technology regularly and continue with professional progression to keep up to date with current topics in the digital world.

Using this type of smartboard technology in teaching produces a youth that is increasingly complex and sophisticated. It makes the process of teaching beneficial for both the educator and the learner.

\subsection{History of the smartboard device}

A smartboard is a device and digital projection panel attached to a large touch sensitive board with projection screen displays the image. The network is controlled directly or with a distinctive pen by contacting the board (Becta, 2003).

In the past, most schools around the world used chalk and a blackboard to teach, but the interactive whiteboard replaced chalk during the technology revolution. Many teachers believe that these electronic boards are a useful digital tool for increasing students' levels of achievement (Schenker \& Kratcoski, 2008).

In 1980 a new idea was introduced, which centred around connecting a computer to a sensitive display panel that acts as an alternative to the computer screen without a mouse or keyboard, using touch to navigate instead. Very few people knew about the presence of the interactive whiteboard until 1991, when David Martin and Nancy Knowlton introduced the first whiteboard through their company Smart Technologies. It provided touch controls equivalent to a computer.

In 1992, Smart Technologies formed a strategic alliance with the American company Intel, which led to further developments in the whiteboard. The company steadily expanded its products to meet the increasing global demand as the interactive board started to spread significantly within the school system.

\subsection{Previous studies}

In 2019, a study conducted by Ahmad and Aladle examined the effect of using an interactive whiteboard on the development of the attitudes and achievements of 8th grade students in terms of learning and cognitive motivation, in primary education in the Sultanate of Oman. A group of 176 students was divided into experimental and control groups. The results showed differences between 
students in both groups in their attitude towards study, cognitive motivation and its dimensions (motivation to learn, risk of knowledge acquisition and use of knowledge) and academic achievement in favor of students using an interactive whiteboard.

Gurbuzturk (2018), conducted a study examining the attitudes of elementary education students to the use of smartboards in classes. The researcher conducted a survey of primary and secondary schools in Malatya province during the 2016-2017 academic year. To sample consisted of the 4th to 8th grade students in three schools, and data was collected using the smartboard attitude scale (SBAS) of Şad (2012). The findings were that students in the elementary stages usually have positive attitudes to using a smartboard. Their attitudes towards the smartboard were impacted by the number of students in the school and the student's grade, but not by gender.

Kaya and Yazıcı (2018) conducted a study of the self-efficacy of social studies teachers using the smart whiteboards. The researchers designed a questionnaire and distributed it to 101 social studies teachers at public secondary schools in Turkey. For statistical analysis of variance, gender, age, whether they had received training on the use of information technology. The results show that the self-efficacy of the sample was at a level of agreement, and there was no effect of gender or age on self-efficacy. Prior training helped to increase self-efficacy in using the interactive whiteboard.

Davidovitch \& Yavich (2017) investigated the effect of the smartboard on the school system. The researchers used a questionnaire and the sample involving of 130 students (boys and girls) who used smartboards in the 5th and 6th grades of two elementary schools in Jerusalem. The findings show that the clarification variable showed the biggest improvement since the start of using the smartboards, in favour of students in the 6th grade, and the variable of interest in supporting the girls. Overall, the study variables appear to be related and the smartboard increased the students' achievement and improved their learning methods. Given the study outcomes, the researchers recommend the teaching technology, because it led to an outstanding level of learning and increased the educational influence of teaching technological improvement.

Oigara (2017) conducted a study investigating the effect of using smartboard technology on the mathematical achievement of fifth grade students. 40 students were nominated and divided into an experimental group who studied mathematics using the smartboard and a control group who studied mathematics using traditional methods and a blackboard. Both groups took an achievement test. The findings reveal a positive effect of using a smartboard on students' mathematical attainment.

In 2016, a study conducted by Almajali and others examined the effectiveness of using a smartboard for teaching social studies on students' achievement in public schools in Jordan. A pre and post test was applied to 258, 120 male and 138 female, 8th grade students in the 2015/2016 academic year to find their level of achievement in social studies. The experimental group were taught by using 
the smartboard while the control group were taught the traditional way. The study findings reveal that there were variations between the classes in favour of the experimental group. There was no difference in the success of the students by gender.

Tunaboylu and Admire (2016) investigated the effect of using an interactive whiteboard in the mathematics teaching of 7th grade students by applying an experimental design. The research findings show that using the interactive whiteboard in the mathematics teaching process had positive effects on the students' mathematical performance.

Dahlan (2014) examined the effect of using an interactive whiteboard on $707^{\text {th }}$ grade students' Arabic language achievement, their leaning acquisition and conservation, and their attitudes towards it. A quasi-experimental approach was used for the study. The researcher divided the students into two groups, experimental and control, and applied two tools an achievement test and an attitude scale. The findings confirm that there were statistical differences between the two groups. The result was in favour of the experimental group. Based on the results, the researcher recommends that it is imperative to supply interactive whiteboards in classrooms and train teachers to use them effectively.

In 2013 A research was performed by Alhumiadan to investigate the impact of using interactive smartboards on the achievement and attitudes of mid-students who study social studies conducted a study aimed to investigate the effect of using interactive smartboards on the achievement and attitudes of middle-stage school students undertaking a social studies curriculum. The sample was divided into two groups, trial and control, and the results were in favour of the experimental group, with the achievement in before and after test performance being improved in the post-test. The findings from the attitude test show no differences in either group, before and after the experiment.

Brand and Bester's (2013) study investigated the effect of technology on attention, motivation, concentration and achievement in a classroom context. A sample of 45 students were selected from the $8^{\text {th }}$ grade and divided into an experimental group who studied lessons in geography, English, and mathematics using technology and a control group who were taught in traditional ways. The study reveals differences in favour of the experimental group in terms of achievement and attention. A highly positive relationship was found between motivation and concentration, and a moderate to high positive connection between focus, concentration and motivation.

In 2013, Abu Hamadah conducted an experimental study aimed at revealing the effect of using a smartboard in geography teaching on the creation of geographic concepts and map skills among 9th graders in the Governorate of Gaza. The research sample consisted of 66 pupils divided into two classes, the control group taught by traditional methods and the experimental group taught using the smartboard. The findings reveal differences between the groups pre- and post-experiment in favour of teaching and developing geographic concepts 
using the smartboard. In light of the study, the researcher recommends the benefit of technological innovation, especially the smartboard, employing it in educational situations and providing schools with smartboards in order to stimulate students and raise their levels of active and positive interaction with the educational content and classroom activities.

In 2008, Swan, Schenker and Kratcoski conducted a study to examine all students in the 3rd through to the 8th grades, it revealed whether students' achievements in English language, art and mathematics improve by using the interactive whiteboard. The researchers compared the scores on state achievement tests between students whose teachers used interactive whiteboards for their teaching and those whose teachers did not. For the students in the interactive whiteboard group, the results show a marginally better performance and students in the 4 th and 5 th grade have the most improvement.

Considering the interest and orientation of the Qatari MoE in integrating technology into education in order to increase student achievement, it is necessary to conduct a study into the impact of smartboards on the effectiveness of teaching social studies and how it affects students' tendencies towards the subject. The following primary and sub research questions are formulated in response to the problems identified by the literature review. The primary question is:

What is the effectiveness of using the interactive smartboard in teaching social studies for preparatory stage students' achievement in Qatar and their tendencies towards the subject?

The first sub-question is:

What is the effectiveness of teaching the unit using the interactive whiteboard in developing levels of remembering, understanding and application of the unit, measured by the cognitive achievement in the study sample?

The following hypotheses are tested to answer the main question:

1. There are no differences between the average scores of students in the trial group and the control group in the pre-measurement of achievement before the trial.

2. There are differences between the average scores of students of the trial group and the control group in the post-measurement of achievement in support of the trial group.

3. There are differences between the average scores of students in the trial group and the control group before and after the trial in support of the trial group. 
The second sub-question is:

What is the effectiveness of teaching the unit using the interactive smartboard in the development of the tendency towards the subject of social studies of the study sample?

To answer the sub-question, the following hypotheses are tested:

1. There are no differences between the average scores of female students of the trial group and the control group in the pre-measurement of tendency towards the subject of social studies before the trial.

2. There are differences between the average scores of students in the trial and control groups in the post-measurement of the tendency towards the subject of social studies in support of the trial group.

3. There are differences between the average scores of students of the trial and control groups before and after the trial measured by the tendency toward the subject of social studies in support of the trial group.

\section{Research Methods}

\subsection{Design and development of research data}

The research adopts a descriptive approach to determining the proposed vision for teaching the target units of the curriculum of social studies at the middlegrade stage using the interactive board. It adopts a quasi-experimental approach to the design and implementation of the experimental part of the study.

The researcher uses two research tools to generate the data. The first is the standardized cognitive achievement test of the three levels of Bloom's taxonomy: remembering, understanding and application of knowledge of the unit and its concepts. The second tool is another standardized measure of the tendency towards social studies in the preparatory stage in three dimensions: the value of social studies as a subject and its function in the lives of students; enjoying studying social studies; and the social studies teacher and their teaching methods. Both tools are applied to both groups before the experiment.

\subsection{Building and codifying the achievement test}

An achievement test is used to measure the levels of remembering, understanding and the application of the knowledge contained in the unit taught. A table of test specifications is constructed. The test consists of 20 multiple-choice questions. A statistical process is used to calculate the relative weight or importance of the two tests. The researcher uses multiple-choice questions because of their objectivity in the results, their ability to cover large areas of the content, their ease of marking, their suitability for students at that stage, and the weak effect of guessing and chance.

Some simple guidelines and test requirements are formulated to make the test clear and valid. The test time is set at minutes, and the test paper is attached to a reply sheet. The test is presented to arbitrators trained in the curriculum and 
some middle stage teachers for their views. A pilot test is carried out on 20 students. The reliability is measured, and Table 1 shows the weights of unit components.

Table 1: The weights of unit components

\begin{tabular}{|c|c|c|c|c|c|c|c|c|}
\hline \multirow[t]{3}{*}{ Lessons } & \multicolumn{6}{|c|}{ Level of achievement test questions } & \multirow{3}{*}{$\begin{array}{l}\text { Content } \\
\text { relative } \\
\text { weight }\end{array}$} & \multirow{3}{*}{$\begin{array}{l}\text { Total } \\
\text { questions }\end{array}$} \\
\hline & \multicolumn{2}{|c|}{ Remembering } & \multicolumn{2}{|c|}{ Understanding } & \multicolumn{2}{|c|}{ Applying } & & \\
\hline & Weight & $\begin{array}{l}\text { Question } \\
\text { number }\end{array}$ & Weight & $\begin{array}{l}\text { Question } \\
\text { number }\end{array}$ & Weight & $\begin{array}{l}\text { Question } \\
\text { number }\end{array}$ & & \\
\hline $\begin{array}{l}\text { Lesson } \\
1\end{array}$ & $30 \%$ & 6 & $18 \%$ & 4 & $12 \%$ & 2 & $60 \%$ & 12 \\
\hline $\begin{array}{l}\text { Lesson } \\
2\end{array}$ & $20 \%$ & 4 & $12 \%$ & 2 & $8 \%$ & 2 & $40 \%$ & 8 \\
\hline Total & $50 \%$ & 10 & $30 \%$ & 6 & $20 \%$ & 4 & $100 \%$ & 20 \\
\hline
\end{tabular}

\subsection{Building a scale of tendency towards social studies}

The researcher has reviewed many studies in the field before building the scale, and of these studies the researchers selects Maghnam (2018), Rahim (2016), Hassan (2016) and Emran (2011). Based on these studies, a scale is constructed with the three dimensions given above (section 3.1). 10 phrases for each of these 3 aspects (30 in total) are presented, half of them positive and half negative. A Likert three-point scale is used for the students to grade their reaction to each expression (agree, not sure, not agree).

The scale is presented to individual arbitrators who specialize in the curriculum and to middle-stage teachers for their views to check the veracity of the content. A pilot test is undertaken with 20 students, to clarify the scaling, and how well the students understood the instructions. The reliability was calculated, and Table 2 shows the relative weights of the scale of the tendency toward the subject of social studies.

Table 2: The relative weights of the scale of the tendency toward the subject of social studies

\begin{tabular}{|l|l|l|l|l|}
\hline Relative & \multirow{2}{*}{ Number } & \multicolumn{2}{|l|}{ Scale phrases } & $\begin{array}{l}\text { Dimensions of the tendency } \\
\text { towards social studies }\end{array}$ \\
\cline { 3 - 5 } & & $\begin{array}{l}\text { Negative } \\
\text { phrases }\end{array}$ & $\begin{array}{l}\text { Positive } \\
\text { phrases }\end{array}$ & $\begin{array}{l}\text { The value of social studies in } \\
\text { the lives of students }\end{array}$ \\
\hline $33.3 \%$ & 10 & $2,4,6,8,10$ & $1,3,5,7,9$ & $\begin{array}{l}\text { Enjoyment of studying social } \\
\text { studies }\end{array}$ \\
\hline $33.3 \%$ & 10 & $12,14,16,18,20$ & $11,13,15,17,19$ & $\begin{array}{l}\text { The social studies teacher and } \\
\text { teaching methods }\end{array}$ \\
\hline $33.3 \%$ & 10 & $22,24,26,28,30$ & $21,23,25,27,29$ & Total \\
\hline $100 \%$ & 30 & 15 & 15 & \multicolumn{2}{|l}{} \\
\hline
\end{tabular}

3.4 Preparing the teaching plan and educational materials for the experiment The 4th unit of the 7th year preparatory curriculum for social studies in the State of Qatar's official curriculum is selected for study. It addresses the "natural and human factors affecting the geographical distribution of the world population". It includes two lessons scheduled for study in 6 classes. To take advantage of all 
the available data the planning learning situations using a smartboard are selected, and the components of the study unit (cognitive domain, psychomotor domain, affective domain) are analyzed for each lesson. The physical, mental, emotional and social growth characteristics of the subject group are considered. The students' previous experience of the components of the unit, and the availability and quality of the technological capabilities of the class are also considered.

Two separate experiment plans are drafted. The first includes six sub-plans for the experimental group in six classes using a smartboard. The second devotes the same number of plans to teaching the unit through traditional blackboard and paper methods. All the lesson plans for each class include a clear definition of the learning outcomes, resources used, concepts involved, teaching strategies implemented, learning activities, structural assessment tools, and how the differentiation between students and enrichment activities for the class are to be achieved.

the first plan integrates all the smartboard tools, focusing on the magic pens, text, pictures, animated video, electronic games, zoom lens, diagrams, twodimensional and three-dimensional representative circuits, stereoscopic maps, digital codes, internet links, mental maps and other miscellaneous tools.

After preparing all the educational material and developing six interactive presentations using the smartboard, the Active Inspire was used as a technological program used in Qatar schools,it was applied to develop the worksheets printed for the activities involved in the experiment. Then a pilot study is undertaken with one of the plans corresponding to the experiment in order to take notes. This is presented to one of the specialist subject teachers for their comments, and thus all the interactive presentations are developed and made ready for use in the class.

Before starting the research experiment in the first semester of 2019, premeasurement was performed on the two groups. The achievement test and tendency scale was applied by the class teacher to the two groups. After testing the two groups statistically, the specific unit was taught to both groups. Teaching the unit took three weeks, with a total of six classes per week, each class being 45 minutes. After three weeks, the unit was complete, and the postmeasurement was done by applying the same achievement test and tendency scale to the two groups.

\subsection{Sample of the study}

The research population is all 7th graders in a government middle school in Qatar, a sample of 47 students from Maria Al-Kobtia elementary school for girls, divided into two groups, the trial group (7th 1) consisting of 25 students from the class. and the control group containing 22 students (7th 2). Both studied the same (4th) unit with and without using a smartboard. 
By reviewing the school records for the two groups, it was confirmed that there was a convergence between the members of the two groups in academic achievement, age, economic level and nationality.

\subsection{Reliability and validity of the tendency scale and achievement test}

To determine the reliability of the questionnaire and test, Guttman's split-half and Cronbach's alpha methods are used. Table 3 shows the reliability of the questionnaire and test. To ensure tool validity, the tool was judged by a group of specialist social studies teachers in schools and faculty members of universities.

Table 3: Reliability of the tendency scale and achievement test

\begin{tabular}{|l|l|l|l|}
\hline Case & Number of items & Cronbach's alpha & $\begin{array}{l}\text { Guttman's Split-Half } \\
\text { Coefficient }\end{array}$ \\
\hline Tendency scale & 30 & 0.640 & 0.809 \\
\hline Achievement Test & 20 & 0.680 & 0.701 \\
\hline
\end{tabular}

\section{Cronbach's alpha}

As shown in Table 3, the values of Cronbach's alpha for the questionnaire and test are 0.640 and 0.680 , respectively. These values are slightly below the acceptable value of 0.70 .

\section{Guttman split-half coefficient}

As shown in Table 3, the values of Guttman's split-half coefficient for the questionnaire and test are 0.809 and 0.701 , respectively. These values are more than the acceptable value of 0.70 , which indicates that the both items have relatively high internal consistency.

\section{Statistical Analysis and Findings}

SPSS (version 26) is used for the analysis of the data to test the study hypotheses. Several advanced analytical techniques are used to study the differences and, for the first and second hypotheses, independent sample T-test, paired sample Ttest, Wilcoxon signed-rank test, and Mann-Whitney U-test. For the third hypothesis, the generalized linear model (GLM) is used.

Table 4: Normality test result in various scenarios

\begin{tabular}{|l|l|l|l|l|}
\hline \multicolumn{5}{|l|}{ Tests of normality (variable) } \\
\hline Group & Survey & Statistic & P-value & Normality \\
\hline Control & Before & 0.933 & 0.14 & Yes \\
\hline Control & After & 0.921 & 0.08 & Yes \\
\hline Treatment & Before & 0.953 & 0.29 & Yes \\
\hline Treatment & After & 0.929 & 0.08 & Yes \\
\hline
\end{tabular}

According to Table 4, in all conditions, the normality assumption is satisfied. So, parametric and non-parametric tests are used in the following. 


\subsection{Analysis of the results of the achievement test}

Three hypotheses were derived from the first study question. A comparison between the trial and control groups in the measure of achievement test before the trial is calculated to test the first hypothesis. Table 5 shows the results.

Table 5: Comparison between the trial and control groups for the measure of achievement before the trial

\begin{tabular}{|c|c|c|c|c|c|c|c|}
\hline \multirow[t]{2}{*}{ Concept } & \multicolumn{2}{|c|}{$\begin{array}{l}\text { Control } \\
\text { group } \\
\mathrm{N}: 22\end{array}$} & \multicolumn{2}{|c|}{$\begin{array}{l}\text { Trial group } \\
\mathrm{N}: 25\end{array}$} & \multirow[t]{2}{*}{$\begin{array}{l}\text { T- } \\
\text { value }\end{array}$} & \multirow[t]{2}{*}{$\begin{array}{l}\text { Z- } \\
\text { value }^{1}\end{array}$} & \multirow[t]{2}{*}{ Note } \\
\hline & Mean & Sd & Mean & Sd & & & \\
\hline Remembering & 4.95 & 1.76 & 4.40 & 2.06 & 0.98 & 0.54 & \multirow{4}{*}{$\begin{array}{l}\text { 1: from } \\
\text { Mann- } \\
\text { Whitney U- } \\
\text { test } \\
* * \text { :significant } \\
\text { at } 1 \%\end{array}$} \\
\hline Understanding & 1.73 & 1.24 & 1.68 & 1.31 & 0.13 & -0.15 & \\
\hline Applying & 1.32 & 0.89 & 1.32 & 0.99 & -0.01 & 0.19 & \\
\hline $\begin{array}{l}\text { Achievement } \\
\text { as a whole }\end{array}$ & 8.00 & 2.62 & 7.40 & 3.38 & 0.67 & 0.53 & \\
\hline
\end{tabular}

The data in table 5 indicates that is approximate values of the mean achievement scores of the female students in the trial and control groups before the trial, in term of remembering, understanding and applying.

The calculated values of $\mathrm{T}$ and $\mathrm{Z}$ indicate no differences, which means equal performance of the two groups on the achievement test before the experiment.

To address the second question, the $\mathrm{T}$ and $\mathrm{Z}$ values are determined as shown in Table 6, a comparison of the trial and control groups on the achievement test after the trial.

Table 6: Comparison between the trial and control groups on the achievement test after the trial

\begin{tabular}{|c|c|c|c|c|c|c|c|}
\hline \multirow[t]{2}{*}{ Concept } & \multicolumn{2}{|c|}{$\begin{array}{l}\text { Control } \\
\text { group N: } 22\end{array}$} & \multicolumn{2}{|c|}{$\begin{array}{l}\text { Trial group } \\
\mathrm{N}: 25\end{array}$} & \multirow[t]{2}{*}{$\begin{array}{l}\mathrm{T}- \\
\text { value }\end{array}$} & \multirow[t]{2}{*}{ Z-value $^{1}$} & \multirow[t]{2}{*}{ Note } \\
\hline & Mean & Sd & Mean & Sd & & & \\
\hline Remembering & 4.27 & 1.72 & 7.28 & 1.93 & $-5.61^{* *}$ & $-4.41^{* *}$ & \multirow{4}{*}{$\begin{array}{l}\text { 1: from Mann- } \\
\text { Whitney U-test }\end{array}$} \\
\hline Understanding & 2.10 & 1.27 & 3.64 & 1.35 & $-4.04^{* *}$ & $-3.69^{* *}$ & \\
\hline Applying & 1.32 & 2.48 & 2.48 & 1.12 & $-3.73^{* *}$ & $-3.36^{* *}$ & \\
\hline $\begin{array}{l}\text { Achievement } \\
\text { as a whole }\end{array}$ & 7.69 & 2.55 & 13.40 & 3.86 & $-5.90 * *$ & $-4.78^{* *}$ & \\
\hline
\end{tabular}

Data in table 6 indicates an average increasing in the mean values of the trial group member scores after the trial compared to the control group members in the complete knowledge of the unit, and each level.

The calculated $\mathrm{T}$ and $\mathrm{Z}$ values for comparison between the groups indicate that there are differences between them in support of the trial group, which improved significantly in the achievement test after studying using a smartboard. To test the third hypothesis, a comparison before and after the trial of the trial group in the achievement test is calculated. Table 7 shows the results. 
Table 7: Comparison before and after the trial of the trial group in the achievement test

\begin{tabular}{|c|c|c|c|c|c|c|c|c|}
\hline \multirow[t]{2}{*}{ Concept } & \multirow[t]{2}{*}{ Sample } & \multicolumn{2}{|c|}{ Pre-measure } & \multicolumn{2}{|c|}{$\begin{array}{l}\text { Post- } \\
\text { measure }\end{array}$} & \multirow[t]{2}{*}{$\begin{array}{l}\text { T- } \\
\text { value }\end{array}$} & \multirow[t]{2}{*}{$\begin{array}{l}\text { Z- } \\
\text { value }^{1}\end{array}$} & \multirow[t]{2}{*}{ Note } \\
\hline & & Mean & Sd & Mean & Sd & & & \\
\hline Remembering & \multirow[t]{4}{*}{25} & 4.40 & 2.06 & 7.28 & 1.93 & $\begin{array}{l}- \\
4.69^{* *}\end{array}$ & $-3.34^{* *}$ & \multirow{4}{*}{$\begin{array}{l}\text { 1: from } \\
\text { Wilcoxon } \\
\text { signed } \\
\text { ranks test } \\
* * \\
\text { significant } \\
\text { at } 1 \%\end{array}$} \\
\hline Understanding & & 1.68 & 1.31 & 3.64 & 1.35 & $\begin{array}{l}- \\
5.20^{* *}\end{array}$ & $-4.23^{* *}$ & \\
\hline Applying & & 1.32 & 0.99 & 2.48 & 1.12 & $\begin{array}{l}- \\
4.13^{* *}\end{array}$ & $-2.72^{* *}$ & \\
\hline $\begin{array}{l}\text { Achievement } \\
\text { as a whole }\end{array}$ & & 7.400 & 3.379 & 13.400 & 3.862 & $\begin{array}{l}- \\
5.66^{* *}\end{array}$ & $-3.55^{* *}$ & \\
\hline
\end{tabular}

Table 7 indicates that an average increasing in the mean of the trial group members' scores after the trial compared to the control group in the areas of overall knowledge of the unit and each aspect.

The calculated of $\mathrm{T}$ and $\mathrm{Z}$ values for comparison between the two groups indicate differences in support of the trial group, which improved significantly in the achievement test after studying using a smartboard.

\subsection{The analysis of the results of the tendency scale}

Three hypotheses are derived from the second question of the study. Comparison is made between the trial and control groups in the measure of tendency towards the subject before the experiment to test the first hypothesis. Table 8 shows the results.

Table 8: Comparison between the trial and control groups in the measure of tendency towards the subject before the experiment

\begin{tabular}{|c|c|c|c|c|c|c|c|}
\hline \multirow{2}{*}{$\begin{array}{l}\text { Dimension of } \\
\text { tendency } \\
\text { towards the } \\
\text { subject of } \\
\text { social studies }\end{array}$} & \multicolumn{2}{|c|}{$\begin{array}{l}\text { Control } \\
\text { group } \\
\mathrm{N}: 22\end{array}$} & \multicolumn{2}{|c|}{$\begin{array}{l}\text { Trial group } \\
\mathrm{N}: 25\end{array}$} & \multirow[t]{2}{*}{$\begin{array}{l}\text { T- } \\
\text { value }\end{array}$} & \multirow[t]{2}{*}{$\begin{array}{l}\text { Z- } \\
\text { Value }^{1}\end{array}$} & \multirow[t]{2}{*}{ Note } \\
\hline & Mean & Sd & Mean & Sd & & & \\
\hline $\begin{array}{l}\text { The value of } \\
\text { social studies } \\
\text { and its } \\
\text { implication in } \\
\text { the lives of } \\
\text { students }\end{array}$ & 1.88 & 0.29 & 1.93 & 0.28 & -0.61 & -1.58 & $\begin{array}{l}\text { 1: from Mann- } \\
\text { Whitney U-test } \\
\text { **: significant at } \\
1 \%\end{array}$ \\
\hline $\begin{array}{l}\text { Enjoyment of } \\
\text { social studies }\end{array}$ & 1.90 & 0.29 & 1.98 & 0.46 & -0.70 & -0.75 & $\begin{array}{l}\text { No statistically } \\
\text { significant difference }\end{array}$ \\
\hline $\begin{array}{l}\text { The social } \\
\text { studies teacher } \\
\text { and teaching } \\
\text { methods }\end{array}$ & 1.92 & 0.30 & 1.97 & 0.30 & -0.54 & -0.60 & \\
\hline $\begin{array}{l}\text { The scale as a } \\
\text { whole }\end{array}$ & 1.90 & 0.21 & 1.96 & 0.26 & -0.81 & -0.83 & \\
\hline
\end{tabular}


This data in table 8 indicates that is a convergence of the mean values of the students in the trial and control groups before the experiment in their responses to the items on the scale for their tendency towards the subject of social studies as a whole, and each of its three dimensions.

The calculated $\mathrm{T}$ and $\mathrm{Z}$ values for comparison indicate no differences, which means an equal performance of the two groups in the tendency before the experiment.

To test the second assumption, comparison between the trial and control groups in the dimensions of the tendency towards the subject after the experiment are calculated. Table 9 shows the results.

Table 9: Comparison between the trial and control groups in the dimensions of tendency towards the subject after the experiment

\begin{tabular}{|l|l|l|l|l|l|l|l|}
\hline $\begin{array}{l}\text { Dimensions of } \\
\text { the tendency } \\
\text { towards the } \\
\text { subject }\end{array}$ & $\begin{array}{l}\text { Control } \\
\text { group N: 22 }\end{array}$ & $\begin{array}{l}\text { Trial group } \\
\text { N: 25 }\end{array}$ & $\begin{array}{l}\text { T- } \\
\text { value }\end{array}$ & $\begin{array}{l}\text { Z- } \\
\text { value }\end{array}$ & Note \\
\cline { 2 - 6 } & Mean & Sd & Mean & Sd & & & \\
\hline $\begin{array}{l}\text { The value of } \\
\text { social studies } \\
\text { and its } \\
\text { implication in } \\
\text { the lives of } \\
\text { students }\end{array}$ & 1.89 & 0.22 & 2.50 & 0.32 & $-7.56^{* *}$ & $-5.06^{* *}$ & $\begin{array}{l}\text { 1: from Mann- } \\
\text { Whitney U-test } \\
* * \text { : significant at } \\
1 \%\end{array}$ \\
\hline $\begin{array}{l}\text { Enjoyment of } \\
\text { studying social } \\
\text { studies }\end{array}$ & 1.99 & 0.34 & 2.63 & 0.29 & $-6.90^{* *}$ & $-5.26^{* *}$ & $\begin{array}{l}\text { There is a } \\
\text { statistically } \\
\text { significant } \\
\text { difference }\end{array}$ \\
\hline $\begin{array}{l}\text { The social } \\
\text { studies teacher } \\
\text { and teaching } \\
\text { methods }\end{array}$ & 1.88 & 0.25 & 2.69 & 0.21 & - & $-5.78^{* *}$ & \\
\hline $\begin{array}{l}\text { The scale as a } \\
\text { whole }\end{array}$ & 1.92 & 0.15 & 2.60 & 0.21 & - & $-5.87^{* *}$ & \\
\hline
\end{tabular}

These data in table 9 indicated to an average increasing in the mean values of the trial group members' scores after the experiment in comparison with the control group members, on the scale of tendency towards the subject of social studies, and each of its three dimensions.

The calculated $\mathrm{T}$ and $\mathrm{Z}$ values for comparison between the two groups indicate variances between them in support of the trial group, which significantly improve their level of tendency towards social studies as a subject after studying it using a smartboard.

For the third hypothesis, a comparison is made between the experimental group before and after the experiment in the dimensions of tendency towards the subject and the results are shown in Table 10. 
Table 10: Comparison before and after the experiment of the trial group in the measurements of tendency towards the subject

\begin{tabular}{|c|c|c|c|c|c|c|c|c|}
\hline \multirow{2}{*}{$\begin{array}{l}\text { Dimensions of } \\
\text { tendency } \\
\text { towards the } \\
\text { subject of social } \\
\text { studies }\end{array}$} & \multirow[t]{2}{*}{ Sample } & \multicolumn{2}{|c|}{ Pre measure } & \multicolumn{2}{|c|}{$\begin{array}{l}\text { Post } \\
\text { measure }\end{array}$} & \multirow[t]{2}{*}{$\begin{array}{l}\text { T- } \\
\text { value }\end{array}$} & \multirow{2}{*}{$\begin{array}{l}Z \text { Z- } \\
\text { value } \\
1\end{array}$} & \multirow[t]{2}{*}{ Note } \\
\hline & & Mean & $\mathrm{Sd}$ & Mean & $\mathrm{Sd}$ & & & \\
\hline $\begin{array}{l}\text { The value of } \\
\text { social studies } \\
\text { and its } \\
\text { implications in } \\
\text { the lives of } \\
\text { students }\end{array}$ & 25 & 1.93 & 0.28 & 2.50 & 0.32 & $-7.17^{* *}$ & $-\overline{4.34^{* *}}$ & $\begin{array}{l}\text { 1: from } \\
\text { Wilcoxon } \\
\text { signed ranks } \\
\text { test } \\
* * \text { : significant } \\
\text { at } 1 \%\end{array}$ \\
\hline $\begin{array}{l}\text { Enjoyment of } \\
\text { studying social } \\
\text { studies }\end{array}$ & & 1.98 & 0.46 & 2.63 & 0.29 & $-7.15^{* *}$ & $-\overline{4.18^{* *}}$ & $\begin{array}{l}\text { There is a } \\
\text { statistically }\end{array}$ \\
\hline $\begin{array}{l}\text { The social studies } \\
\text { teacher and } \\
\text { teaching } \\
\text { methods }\end{array}$ & & 1.97 & 0.30 & 2.69 & 0.21 & $\begin{array}{l}- \\
10.30^{*} \\
*\end{array}$ & $-\overline{4.29^{* *}}$ & $\begin{array}{l}\text { significant } \\
\text { difference }\end{array}$ \\
\hline $\begin{array}{l}\text { The scale as a } \\
\text { whole }\end{array}$ & & 1.96 & 0.27 & 2.60 & 0.21 & $\begin{array}{l}- \\
10.96^{*} \\
*\end{array}$ & $-\overline{4.38^{* *}}$ & \\
\hline
\end{tabular}

These data in table 10 indicated to an average increasing of the trial group members' scores after the experiment in their tendency towards the subject of social studies and each of its three dimensions.

The calculated $\mathrm{T}$ and $\mathrm{Z}$ values comparing the two measurements before and after show variances between all factors in support of the trial group, which significantly improved their tendency towards social studies as a subject after studying it using a smartboard.

\subsection{Testing the interaction effect on the tendency before and after}

To show whether there is any statistically significant interaction between the tendency before and after the experiment, the GLEM test is used. Table 11 shows the results.

Table 11: The interaction effect on the tendency before and after

\begin{tabular}{|l|l|l|l|l|l|}
\hline Source & SS & df & MS & F & P-Value \\
\hline Intercept & 0.267 & 1 & 0.267 & 0.025 & 0.875 \\
\hline Before-After & 34.392 & 1 & 34.392 & 3.195 & 0.077 \\
\hline Tendency & 147.497 & 1 & 147.497 & 13.704 & 0.000 \\
\hline Interaction & 45.268 & 1 & 45.268 & 4.206 & 0.043 \\
\hline Error & 968.680 & 90 & 10.763 & & \\
\hline Total & 9477 & 94 & & & \\
\hline
\end{tabular}


As shown in Table 11, the interaction effect before and after on the tendency is statistically significant, which means that the tendency after the experiment changed, compared to before.

\subsection{Testing the interaction effect on the tendency between the control and experimental group}

To show whether there is any statistically significant effect between the control and experimental groups or bias, the GLEM test is used. Table 12 shows the results.

Table 12: The interaction effect on the tendency between the control and experimental groups

\begin{tabular}{|l|l|l|l|l|l|}
\hline Source & SS & df & MS & F & P-Value \\
\hline Intercept & 3.405 & 1 & 3.405 & 0.317 & 0.575 \\
\hline Control-Treatment & 64.887 & 1 & 64.887 & 6.044 & 0.016 \\
\hline Tendency & 48.247 & 1 & 48.247 & 4.494 & 0.037 \\
\hline Interaction & 69.242 & 1 & 69.242 & 6.450 & 0.013 \\
\hline Error & 966.239 & 90 & 10.736 & & \\
\hline Total & 9477 & 94 & & & \\
\hline
\end{tabular}

As shown in Table 12, the interaction effect on the tendency between the control and experimental groups is statistically significant, in favour of the experimental group.

\section{Discussion}

The results of the experiment reveal an increase in the achievement of the students in the experimental group who studied using the interactive smartboard, in remembering, understanding and the application of knowledge. This outcome is consistent with the results Alhumaidan (2013), Al Hassan and Al Badawi (2016), Abu Hamadah (2013), Davidovitch \& Yavich (2017), Ahmad and Aladle (2019) and Tunaboylu \& Demir (2017).

The study result are explained by the fact that the interactive smartboard allows the teaching of the unit information to the students in a typically interesting, attractive and flexible way. A variety of media and tools are applied, such as electronic games, images, 2D and 3D charts and multiple maps, using electronic pens.

The smartboard allows the students to positively engage several senses with the lesson plan, helping to simplify and explain the information provided, emphasizing the interrelationships, and providing various applications and examples.

The variety of interactive smartboard tools help in various activities, individually and collectively, and the content is rich. These activities are suitable for the various levels of female student during the study of the unit. The results also show an increase in the tendency of the female students towards the subject 
of social studies after using the smartboard which creates a stimulating and exciting learning environment, which differs from the traditional learning style and allows them to enjoy learning in the modern technological style preferred by the current generation at this stage.

The multimedia presented using the smartboard contributes to satisfying the student's curiosity and exploring issues. It facilitates learning it in a functional style related to the students' daily lives, reducing the difficulty of social studies compared to the subject taught in its traditional way.

In addition to differentiating the teaching strategies used in lessons with the smartboard, the teacher who applied the experiment engaged the students because of her previous training on smartboards. This may be a reason for the increase in the students' positive tendency towards the subject, the teacher of the subject and the teaching methods. This is a clear result consistent with previous results that verify the negative feelings and some of the difficulties and disinterest students feel while studying social studies in the traditional way. This outcome is consistent with the results of Gurbuzturk (2018), Oigara (2017), Dahlan (2014) and Alhumiadan (2013).

\section{Conclusion}

In conclusion, this study provides evidence that using a smartboard increases students' levels of achievement and their tendency toward social studies. The students saw a positive trend in their learning capability by using a smartboard. This investigation suggests that learning using technology is an urgent need at present, and this technology must be incorporated into teaching because of its effectiveness in increasing achievement.

The research has practical implications for Qatar's learning system. Students are able to develop their tendency, increase their achievement and skill, and build their learning capability in social studies subjects. The overall analysis confirms that, by using a smartboard, teachers can help students secure a positive tendency and excellent achievement.

\section{Recommendations:}

1- The use of a smart board should be one of the standards for teaching social studies in the State of Qatar

2- Provide training workshops for teachers on using the smart board effectively

3- The researcher should benefit from the results of this study by conducting similar studies in different subjects and for different levels

4- Mainstreaming the use of a smart board in teaching social studies to schools in the State of Qatar for its importance in increasing achievement

\section{References}

Abdelhamid, F. (2016). Smartboard (Interactive). Journal of E-Learning [online]. Retrieve from: http://emag.mans.edu.eg/index.php?page=news\&task=show\&id=144

Abu Hamadah, S. (2013). The Effect of Employing Smartboard-in Teaching Geography-on Developing Geographic Concepts and Using Maps Skill among Nine Graders in Gaza 
Governorate. Unpublished Masters dissertation. The University of Alazhar, Ghaza.

Abu, M., \& Karami, B. (2018). The effectiveness of using the PDEODE strategy for teaching social studies in developing geographical concepts and geographical thinking skills and the tendency towards geography among first intermediate students. Journal of Educational Sciences - Imam Muhammad bin Saud University Saudi Arabia, 13, 411-477. https://doi.org/10.12816/0045584

Adel, M. A., \& Abdelrahman, M. A. (2019). The effects of using an Electronic Interactive Whiteboard in Developing students Attitude, Cognitive Motivation and Academic achievement. Journal of Education and Practice 10(10), 124-129. https://doi.org/10.12816/0045584

Al Hassan, E. I. K., \& Al Badwi, M. M. (2016). The Effect of Using the Smartboard in the Acquisition for the Pupils in the 8th Class of the Basic Education Stage at Khartoum locality in the Lesson of Science in Our Life. Journal of the College of Basic Education for Educational and Human Sciences, Babel University, 26.

Alhumaidan, I. A. (2013). The effect of using Smartboard on students' achievement and attitudes toward social studies curriculum. Journal of Education and Psychology, $41,5-25$

Al-Majali, H. K., Al Abdallah, S. E., \& Shamayleh, N. (2016). The effectiveness of using smartboard for teaching social studies at public schools in Jordan. Global Science Research Journal, 4(1), 227-233.

Bates, T. (2003). Effective Teaching with Technology in Higher Education: Foundations for Success. San Francisco: Jossey-Bass.

Becta, A. (2003). What research says about interactive whiteboards [online]. Retrieve from: http://www.ttrb.ac.uk/ViewArticle2.aspx?ContentId=12434.

Bester, G., \& Brand, L. (2013). The effect of technology on learner attention and achievement in the classroom. South African Journal of Education, 33(2). https://doi.org/10.12816/0045584

Chaaban, Y., \& Ellili-Cherif, M. (2017). Technology integration in EFL classrooms: A study of Qatari independent schools. Education and Information Technology 22, 2433-2454. https:// doi.org/10.12816/0045584

Collins, A., \& Halverson, R. (2009). Rethinking Education in the Age of Technology: The Digital Revolution and Schooling in America. New York: Teachers College Press.

Cox, J. (2019). Technology in the Classroom: The Benefits of Smart Boards [online]. Available at: https:/ / www.teachhub.com/technology-classroom-benefits-smart-boards.

Dahlan, O. (2014). the effect of using the Interactive Whiteboard on the students' Arabic language achievement and the leaning acquisition conservation for the 7th grade and their attitudes towards it. Almanarah Journal, 20(20).

Davidovitch, N., \& Yavich, R. (2017). The Effect of Smartboards on the Cognition and Motivation of Students. Higher Education Studies Journal, 7(1), 60. https://doi.org/10.12816/0045584

El-Masri, M., \& Tarhini, A. (2017). Factors affecting the adoption of e-learning systems in Qatar and USA: Extending the Unified Theory of Acceptance and Use of Technology 2 (UTAUT2). Education Technology Research and Development, 65, 743763. https:// doi.org/10.12816/0045584

Gurbuzturk, O. (2018). Investigation of Elementary Education Students' Attitudes towards the Use of Smartboards. International Electronic Journal of Elementary Education, 11(1), 55-61. https:// doi.org/10.26822/iejee.2018143961

Hassan, H. A. S. (2016). The effect of incorporating digital storytelling in the stages of the learning cycle to develop some of the products of geography learning for students with low vision in the elementary stage. Journal of the Educational 
Association for Social Studies: Ain Shams University - College of Education, 83, 119148.

Imran, M. S. M. (2014). The effectiveness of a suggested program based on some activities to develop geographical thinking skills and a tendency towards the social studies of first stage primary students. Journal of the Educational Association for Social Studies: Ain Shams University - College of Education, 61, 149-165.

Kaya, M. T., \& Yazıc1, H. (2018). Self-Efficacy of the Social Studies Teachers in Using the Interactive Whiteboards. Review of International Geographical Education Online, 8(3), 601-612. https://doi.org/10.26822/iejee.2018143961

Qatar Ministry of Education and Higher Education (2019) [online]. Available at: http://www.edu.gov.qa/Ar/SECInstitutes/EducationInstitute/CS/SocialScinc e/Pages/default.aspx

Nusir, S., Alsmadi, I., Al-Kabi, M., \& Sharadgah, F. (2012). Studying the Impact of Using Multimedia Interactive Programs at Children Ability to Learn Basic Math Skills. Acta Didactica Napocensia, 5(2),17-32. https://doi.org/10.2304/elea.2013.10.3.305

Oigara, J. (2017). Teaching and Learning with Smartboard Technology in the Elementary Classroom. In P. Resta \& S. Smith (Eds.) Proceedings of Society for Information Technology \& Teacher Education International Conference (pp. 896-899). Austin, TX: Association for the Advancement of Computing in Education.

Rahim, A. A. O., Fikri, H. A. R., Marwa, H. I. T., \& Doaa, M. M. D. (2016). The effectiveness of using the Courts program in teaching geography to develop contemplative thinking skills and a tendency toward material among middle school students. Journal of Scientific Research in Education, 17(2), 45-66.

Rorty, A. (2005). Philosophers on Education: Historical Perspectives. London and New York: Routledge. https://doi.org/10.4324/9780203981610

Swan, K., Schenker, J., \& Kratcoski, A. (2008). The Effects of the Use of Interactive Whiteboards on Student Achievement. In J. Luca \& E. Weippl (Eds.), Proceedings of ED-MEDIA 2008 World Conference on Educational Multimedia, Hypermedia $\mathcal{E}$ Telecommunications (pp. 3290-3297). Vienna, Austria: Association for the Advancement of Computing in Education. https://doi.org/10.4018/978-161520-715-2.ch009

Tunaboylu, C., \& Demir, E. (2017). The Effect of Teaching Supported by Interactive Whiteboard on Students' Mathematical Achievements in Lower Secondary Education. Journal of Education and Learning, 6(1). https://doi.org/10.18844/prosoc.v2i7.1988

Üstünel, E., \& Aitkuzhinova-Arslan, A. (2014). The influence of smart board technology on student engagement in and perception of classroom activities. European Journal of Research on Social Studies, 1(1), 42-46. https://doi.org/10.15526/ejrss.201416203 